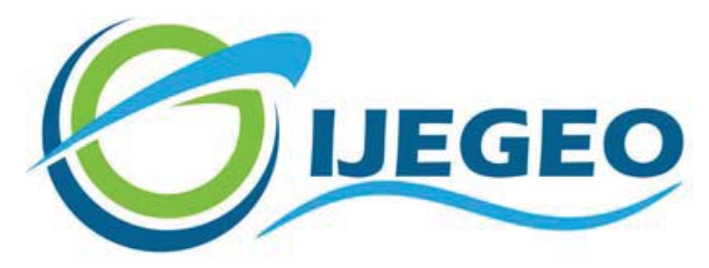

International Journal of Environment and Geoinformatics (IJEGEO) is an international, multidisciplinary, peer reviewed, open access journal.

\title{
Delineation of Groundwater Potential Zones in Rajkot Tehsil, Gujarat, Using Remote Sensing and GIS Techniques
}

\section{Jignasha PATEL}

\author{
Chief in Editor \\ Prof. Dr. Cem Gazioğlu \\ Co-Editors
}

Prof. Dr. Dursun Zafer Şeker, Prof. Dr. Şinasi Kaya,

Prof. Dr. Ayşegül Tanık and Assist. Prof. Dr. Volkan Demir

Editorial Committee (September 2021)

Assoc. Prof. Dr. Abdullah Aksu (TR), Assit. Prof. Dr. Uğur Algancı (TR), Prof. Dr. Bedri Alpar (TR), Assoc. Prof. Dr. Aslı Aslan (US), Prof. Dr. Levent Bat (TR), Prof. Dr. Paul Bates (UK), İrşad Bayırhan (TR), Prof. Dr. Bülent Bayram (TR), Prof. Dr. Luis M. Botana (ES), Prof. Dr. Nuray Çağlar (TR), Prof. Dr. Sukanta Dash (IN), Dr. Soofia T. Elias (UK), Prof. Dr. A. Evren Erginal (TR), Assoc. Prof. Dr. Cüneyt Erenoğlu (TR), Dr. Dieter Fritsch (DE), Prof. Dr. Çiğdem Göksel (TR), Prof.Dr. Lena Halounova (CZ), Prof. Dr. Manik Kalubarme (IN), Dr. Hakan Kaya (TR), Assist. Prof. Dr. Serkan Kükrer (TR), Assoc. Prof. Dr. Maged Marghany (MY), Prof. Dr. Michael Meadows (ZA), Prof. Dr. Nebiye Musaoğlu (TR), Prof. Dr. Masafumi Nakagawa (JP), Prof. Dr. Hasan Özdemir (TR), Prof. Dr. Chryssy Potsiou (GR), Prof. Dr. Erol Sarı (TR), Prof. Dr. Maria Paradiso (IT), Prof. Dr. Petros Patias (GR), Prof. Dr. Elif Sertel (TR), Prof. Dr. Nüket Sivri (TR), Prof. Dr. Füsun Balık Şanlı (TR), Prof. Dr. Uğur Şanlı (TR), Duygu Ülker (TR), Prof. Dr. Seyfettin Taş (TR), Assoc. Prof. Dr. Ömer Suat Taşkın (TR), Assist. Prof. Dr. Tuba Ünsal (TR), Dr. Manousos Valyrakis (UK), Dr. İnese Varna (LV), Dr. Petra Visser (NL), Prof. Dr. Selma Ünlü (TR), Assoc. Prof. Dr. Oral Yağcı (TR), Prof. Dr. Murat Yakar (TR), Assoc. Prof. Dr. İ. Noyan Yılmaz (AU); Assit. Prof. Dr. Sibel Zeki (TR) 


\title{
Delineation of Groundwater Potential Zones in Rajkot Tehsil, Gujarat, Using Remote Sensing and GIS Techniques
}

\author{
Jignasha Patel \\ Civil Engineering, Darshan Institute of Engineering \& Technology, Rajkot, India
}

E-mail: patel.jignasha9693@gmail.com

Received 10 Apr 2020

Accepted 10 Feb 2021

How to cite: Patel, J. (2020). Delineation of groundwater potential zones in Rajkot tehsil, Gujarat, using remote sensing and GIS techniques.

International Journal of Environment and Geoinformatics (IJEGEO), 8(3), 276-282. . doi. 10.30897/ijegeo. 718029

\begin{abstract}
A Precious natural asset and prime natural resource for the basic need for a human is water. Groundwater which is commonly available as freshwater sources beneath the earth's surface is widely used in many parts of the world for domestic and agricultural activities. In this present work, the groundwater potential zone identification is done by using remote sensing and GIS. The thematic maps like soil, rainfall, drainage, DEM and land use land cover map has been used. The groundwater potential zone map is generated by assigning weightage to various thematic maps using weighted overlay analysis and the groundwater prospective zone of the study area was classified into 5 categories viz., very poor, poor, good, very good and excellent. As the study area is covered under water scared area and throughout the year human activities are depended on the ground water, so the ground water management is necessary so as in this study GIS \& RS technique is used, using weighted overlay analysis thematic maps were prepared. The result depicts the groundwater potential zones in the study area and found to be helpful in better planning and management of groundwater resources.
\end{abstract}

\section{Keywords: Groundwater potential zones; India; remote sensing; GIS, Rajkot (Gujarat, India) \\ Introduction}

Groundwater is a vital natural resource for the reliable and economic provision of potable water supply in both urban and rural environment. Hence it plays a fundamental role in human well-beings, as well as that of some aquatic and terrestrial ecosystems. At present, groundwater contributes around $34 \%$ of the total annual water supply and is an important fresh water resource. So, an assessment for this resource is extremely significant for the sustainable management of groundwater systems. GIS and remote sensing tools are widely used for the management of various natural resources (Dar et al., 2010; Krishna Kumar et al., 2011; Magesh et al., 2011).

Delineating the potential groundwater zones using remote sensing and GIS is an effective tool. In recent years, extensive use of satellite data along with conventional maps and rectified ground truth data, has made it easier to establish the base line information for groundwater potential zones (Tiwari and Rai, 1996; Das et al., 1997; Thomas et al., 1999; Harinarayana et al., 2000; Muralidhar et al., 2000; Chowdhury et al., 2010). Remote sensing not only provides a wide-range scale of the space-time distribution of observations, but also saves time and money (Murthy, 2000; Leblanc et al., 2003; Tweed et al., 2007). In addition it is widely used to characterize the earth surface (such as lineaments, drainage patterns and lithology) as well as to examine the groundwater recharge zones (Sener et al., 2005).
The water available in the surface bodies of Rajkot Tehsil regions in the tanks and the reservoirs are not sufficient. Hence the groundwater resources in Rajkot Tehsil, Gujarat, India are being continuously exploited to meet the demand of the water supply and irrigation (Kalubarme et al., 2019; Chauhan et al., 2021; Panchal et al., 2021). Hence it is essential to assess the groundwater quality for the extraction, identification of the potential zones and the recharge sites using Remote Sensing and GIS, which is an emerging as a great public concern in this region.

Integration of remote sensing with GIS for preparing various thematic layers, such as drainage density, rainfall, slope, soil, and land-use \& land cover with assigned weightage in a spatial domain will support the identification of potential groundwater zones. Therefore, the present study focuses on the identification of groundwater potential zones in Rajkot tehsil, Gujarat using the advanced technology of remote sensing, and GIS for the planning, utilization, administration, and management of groundwater resources.

\section{Study Area}

Rajkot is located at $22.3^{\circ} \mathrm{N} 70.78^{\circ} \mathrm{E}$. It has an average elevation of 128 metres $(420 \mathrm{ft})$. The city is located on the bank of Aji River and Nyari River which remains dry except the monsoon months of July to September. Rajkot has a semi-arid climate, with hot, dry summers from mid-March to mid-June and the wet monsoon season from mid-June to October, when the city receives $590 \mathrm{~mm}$ of rain on average. The months from November 
to February are mild, the average temperature being around $20^{\circ} \mathrm{C}$, with low humidity.

One of the most important weather phenomena that is associated with the city of Rajkot is the cyclone. The cyclones generally occur in the Arabian Sea during the months after the rainy season. The region experiences a lot of rainfall and high-speed winds during the time of the year after the monsoon season as well as the months of May and June. However, June experiences lesser amount of rainfall and winds than the post-monsoon time. Thunderstorms are another important part of the Rajkot weather in the months of June and July. During summer time, the temperature ranges between $24{ }^{\circ} \mathrm{C}$ and $42{ }^{\circ} \mathrm{C}$. In the months of winter, Rajkot temperature varies between $10{ }^{\circ} \mathrm{C}$ and $22{ }^{\circ} \mathrm{C}$ but on a whole winters are pleasant. (District census handbook Rajkot, Census of India 2011). The average rainfall during the year 2011 to 2018 is as low as $754 \mathrm{~mm}$. Due to this climatic condition various human activity other than monsoon season depended on groundwater. Hence, groundwater plays a vital role in the development of this area. Annual Replenishable Ground Water Resources for the Rajkot district is $1528.25 \mathrm{MCM}$ (District groundwater brochure, Rajkot district, CGWB), for exploration this good quantity of water throughout the year it is required to identify the groundwater potential zone for this area.

\section{Ground Water Scenario}

Groundwater is the water present beneath Earth's surface in soil pore spaces and in the fractures of rock formations. The depth at which soil pore spaces or fractures and voids in rock become completely saturated with water is called the water table. Groundwater is also often withdrawn for agricultural, municipal, and industrial use by constructing and operating extraction wells (Khorrami et al., 2018).

Hydro-geologically the district can be broadly divided into three i.e Dhrangadhra Sandstone of Cretaceous period, Deccan Trap basalt and alluvium. The depth to water level in the district ranges from 0.78 to $22.45 \mathrm{mbgl}$ during the pre-monsoon period with $70 \%$ of the stations showing water level less than $10 \mathrm{~m}$. Maliya village has recorded the shallowest water level whereas the deepest water level was recorded at Pedhla village. During the post monsoon period the depth to water level ranged from $1.68 \mathrm{mbgl}$ at Morbi village to $21.97 \mathrm{mbgl}$ at Pedhla village with about $85 \%$ of the station showing water level less than $10 \mathrm{~m}$. Analysis of the long-term groundwater level trend for 10 years from 2003-2012 of the district reveals that rise in groundwater level predominant throughout the district. Long term rise in water level during the pre-monsoon period ranged from 0.01 to $0.70 \mathrm{~m} / \mathrm{yr}$ while the fall ranged from 0.01 to 0.16 $\mathrm{m} / \mathrm{yr}$. The highest rise was recorded at Ganod village while the highest fall was recorded at Jetpur Village. The long term water level fluctuation for the Post monsoon period also reveals that rise in groundwater level is predominant thought out the entire district with rise in water level ranging from 0.0056 to $0.76 \mathrm{~m} / \mathrm{yr}$ while fall recorded in the district ranged from 0.013 to
$0.88 \mathrm{~m} / \mathrm{yr}$. Upleta village recorded the highest rise during the post monsoon period whereas Targhadi village recorded the highest fall (District groundwater brochure, Rajkot district, CGWB).

The suitable recharge structures feasible in the district are Percolation tanks/ponds; Recharge wells check dams and nalla bunds etc. depending on the hydrogeological conditions. In the entire hard rock terrain, scope exists for augmenting the groundwater resources through the artificial recharge. Large scale artificial recharge schemes may not be feasible due to non-availability of prolific aquifers and paucity of source water. There is an urgent need for management of resources for sustainable development.

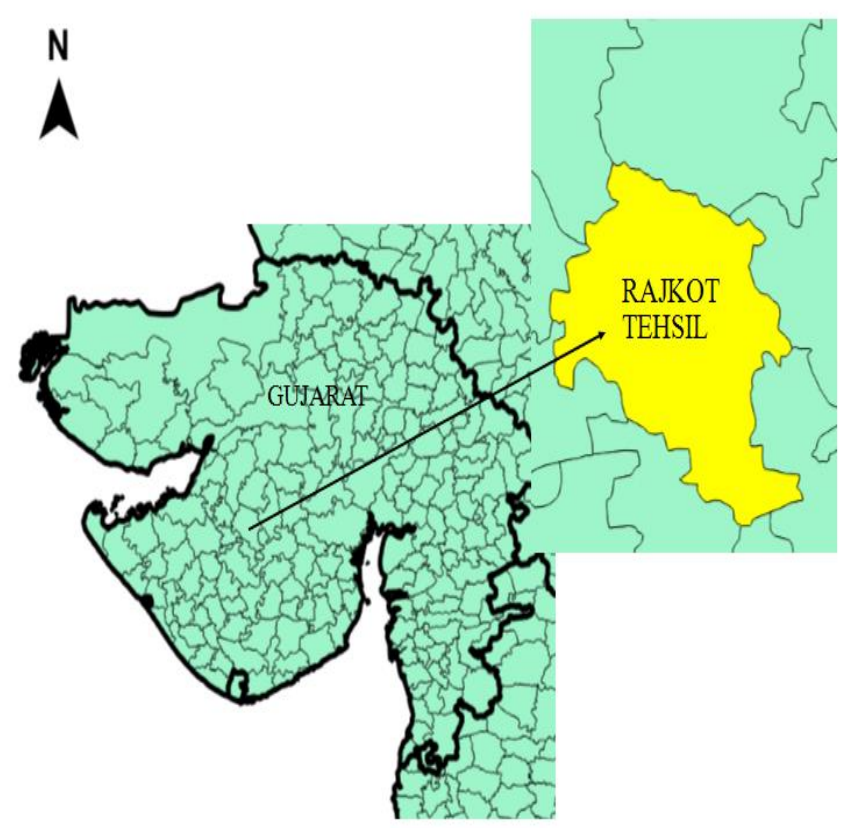

Figure 1. Location of Study Area

\section{Methodology}

The methodology adopted for the present study is shown in Fig. 2. The base map of Rajkot tehsil was prepared using a shape file of the India for village level on a 1:25,000 scale. The slope map was prepared from SRTM DEM data in Spatial Analyst module. Same the drainage network has been prepared from the hydrological analysis tool. The rainfall map was prepared using the data obtained from the Climatic Research Unit (CRU) data sets. These data were then spatially interpolated using kriging method to obtain the rainfall distribution map. The drainage density map has been prepared using the line density analysis tool in ArcGIS. Satellite images from LANDSAT 8 on a scale of 1:50,000 (geo-coded, with UTM projection, spheroid and datum WGS 84, Zone 42 North) have been used for delineation of thematic layers such as land-use landcover and soil types. These thematic layers were converted into a raster format $(30 \mathrm{~m}$ resolution) before they were brought into GIS environment (Gazioğlu et al., 2014). The groundwater potential zones were 
obtained by overlaying all the thematic maps in terms of weighted overlay methods using the spatial analysis tool in ArcGIS. During weighted overlay analysis, the ranking was given for each individual parameter of each thematic map, and weights were assigned according to the multi influencing factor (MIF) of that particular feature on the hydro-geological environment of the study area. (Shaban et al., 2006).

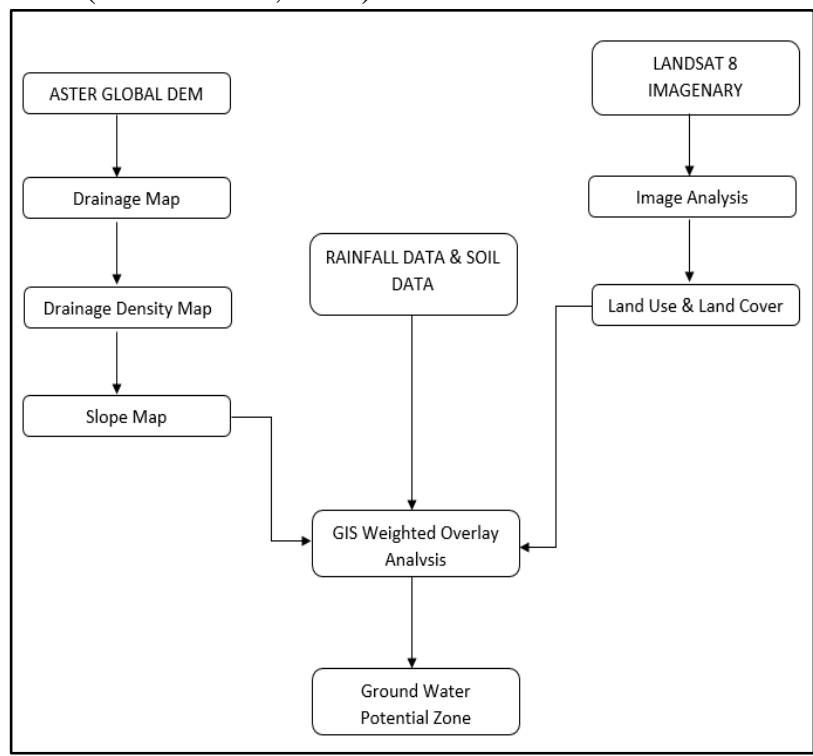

Figure 2. Flowchart for delineating GW potential zone

\section{Result and Discussion \\ Land-use and Land-cover}

Land cover/land use is a significant factor affecting the recharge process. This factor involves a number of elements but the major ones are the soil deposits, human settlements and vegetation cover. The major effect of soil deposits on water percolation into the subsurface media is attributed to its clayey content, as it controls the retention capacity of water. It is usually related to the terrain slope. Their geographic distribution in the study area is obviously different. Isolated thin soil deposits can be found in the mountainous regions, while thick and well-developed soil deposits are located on relatively flat areas. However, thick accumulations of soil deposits reduce the rate of water percolation. The human settlement has a definite role in retarding the recharge process. Man-made constructions, such as concrete embankments, buildings, hangars, roads, etc. create a compacted terrain that seals the ground surface, thus preventing water to recharge easily (Bou Kheir et al. 2003). Vegetation cover can be considered as an enhancing one, notably in the Mediterranean extreme climate (Darwich et al. 2003; ). In this respect, the higher the vegetation cover, the higher the evapotranspiration rate and this implies less chance for percolation to the subsurface layers. But the density of the cover has to be considered as well as its geographic extent. Nevertheless, these processes are contradictory. First, the biochemical disruption of the terrain surfaces, whether it is soil or rock, by the roots and organisms. Second is that the vegetal cover helps in confining the water under the vegetal zone (in an umbrella scheme), therefore preventing water from direct evaporation. The third is the ability of plants to hold soil in place rather than to erode with an increase in water runoff. In summary, it can be assumed that the vegetation cover is an effective factor in the enhancement of recharge rate.

The major land-use type in the study area is barren land, Agricultural land, waterbodies, urban area and plantations. These land use classes are delineated from LANDSAT 8 imaginary (Fig. 3). Around 16\% area is covered under urban type, $77 \%$ is agriculture, $5 \%$ is barren land and $2 \%$ covered by water bodies.

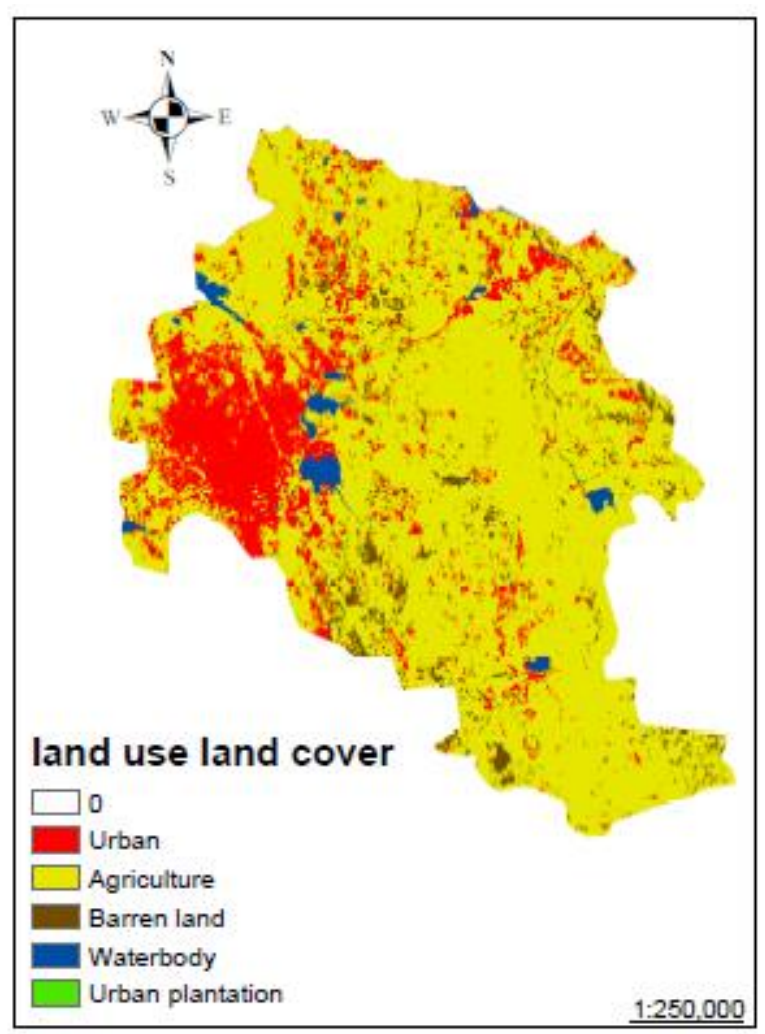

Figure 3. Landuse and Landcover

\section{Drainage density}

Another input to help evaluate the recharge property can be realized by detailed morphometric analysis of the drainage network. This character is determined fundamentally by the underlying lithology, and thus provides an important indication of water percolation rate. Many workers combined only the lineament map with drainage map to presume the target areas of groundwater potential areas (Tomes 1975; Edet et al. 1998; Menteş et al., 2019). Normally, the most important morphometric properties of a drainage system are: drainage density, frequency of intersection of drainage lines, length of the 1st order streamlines, bifurcation ratio and drainage pattern. It is well known that the denser the drainage network, the less recharge rate and vice versa. Nevertheless, in Occidental Lebanon, this approach was found to give erroneous results in certain instances (Shaban et al. 2004). For example, within the known high recharge rock formations, notably those of the karstified dolomitic limestone, dense drainage networks are originated (Barut, 2015). This can be attributed to the presence of highly competent rocks. This in turn creates a number of flow paths, usually with relatively short lengths at the 
surface. However, a comparative study was applied to find out the relationship of coincidence between the known recharge rates of different rock formations in the study area and the most relevant morphometric property.

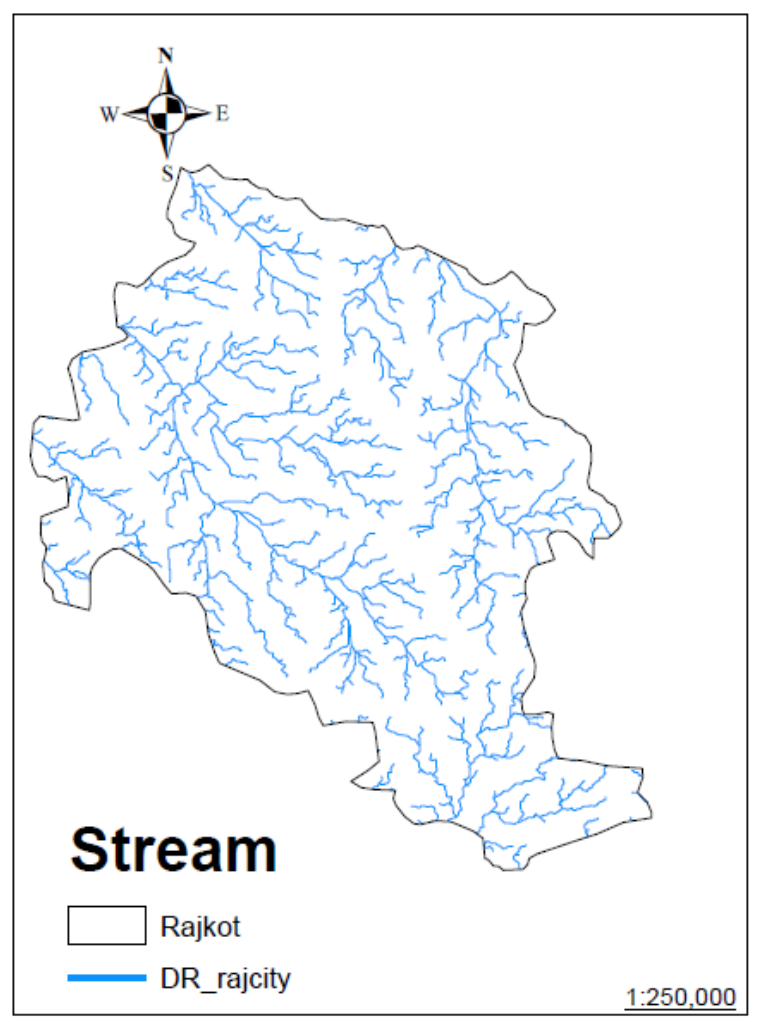

Figure 4. Drainage network of study area

The higher the frequency in the number of stream tributaries, the more recharge occurs. Drainage density is defined as the closeness of spacing of stream channels. It is a measure of the total length of the stream segment of all orders per unit area. The drainage density is an inverse function of permeability. The less permeable a rock is, the less the infiltration of rainfall, which conversely tends to be concentrated in surface runoff. Drainage density of the study area is calculated using line density analysis tool in ArcGIS software. The study area has been grouped into five classes. These classes have been assigned to minimum 0 to maximum 2.694500208 value (Fig. 5). The suitability of groundwater potential zones is related to drainage density because of its relation with surface runoff and permeability. Drainage density map has been prepared from the drainage network of the study area (Fig. 4).

\section{Slope}

Slope is an important factor for the identification of groundwater potential zones. Higher degree of slope results in rapid runoff and increased erosion rate with feeble recharge potential. The slope map of the study area was prepared based on ASTER GDEM data using the spatial analysis tool in ArcGIS. Slope grid is identified as "the maximum rate of change in value from
It was found that the drainage number (frequency) has the strongest relationship with the recharge property (Shaban 2003).

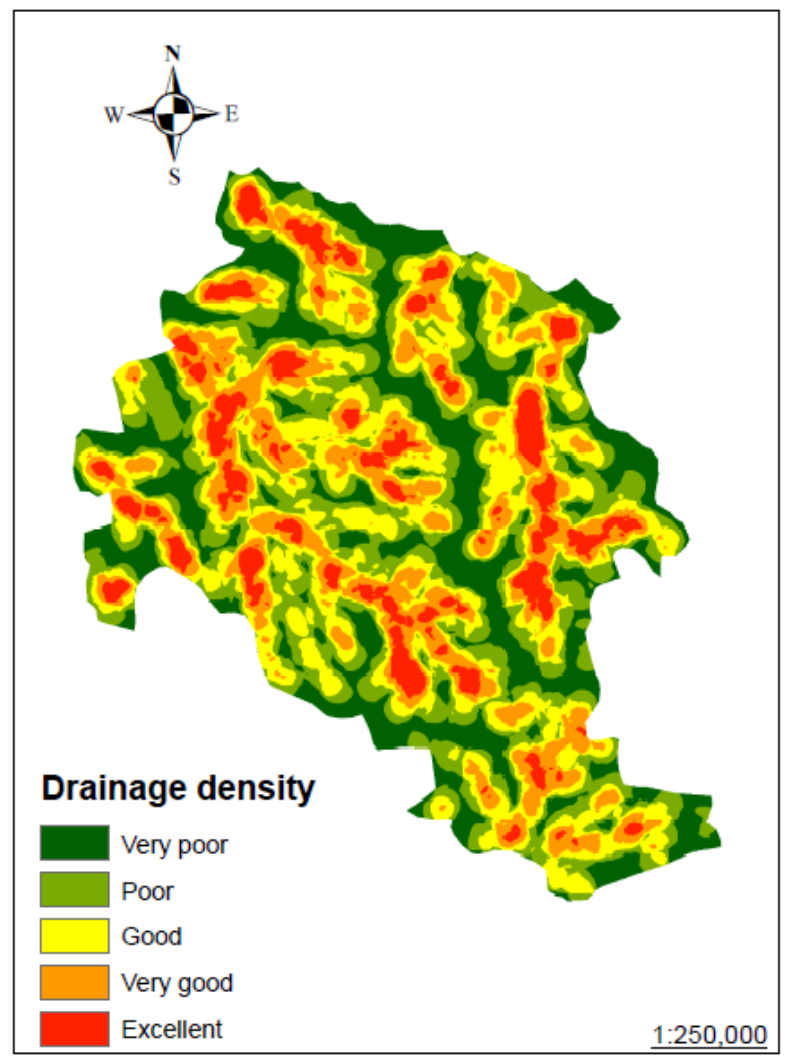

Figure 5. Drainage density

each cell to its neighbors". Based on the slope, the study area can be divided into five slope classes. These classes have been assigned to minimum 0 to maximum 38.00751877 value (fig.6). The areas having lower slope fall into the 'very good' category because of the nearly flat terrain and relatively high infiltration rate. Areas having higher slope considered as low infiltration rate.

\section{Rainfall}

Records of the rainfall are available in the Rajkot Meteorological Observatory Station. The annual rainfall in the district is received during the south-west monsoon season from June to September. July being the month with the highest rainfall. The variation of rainfall over the districts from year to year is large. The frequency being more during the period May to October Occasional fog occurs during the post-monsoon months and winter season.

In association with cyclonic storms in the Arabian Sea in the post- monsoon months and to a lesser extent in May and June; the district experiences very strong winds and widespread rain. Thunder storms occur practically in all the months. For this study rainfall data of the year 2018 has been used which is maximum $447.3 \mathrm{~mm}$. 


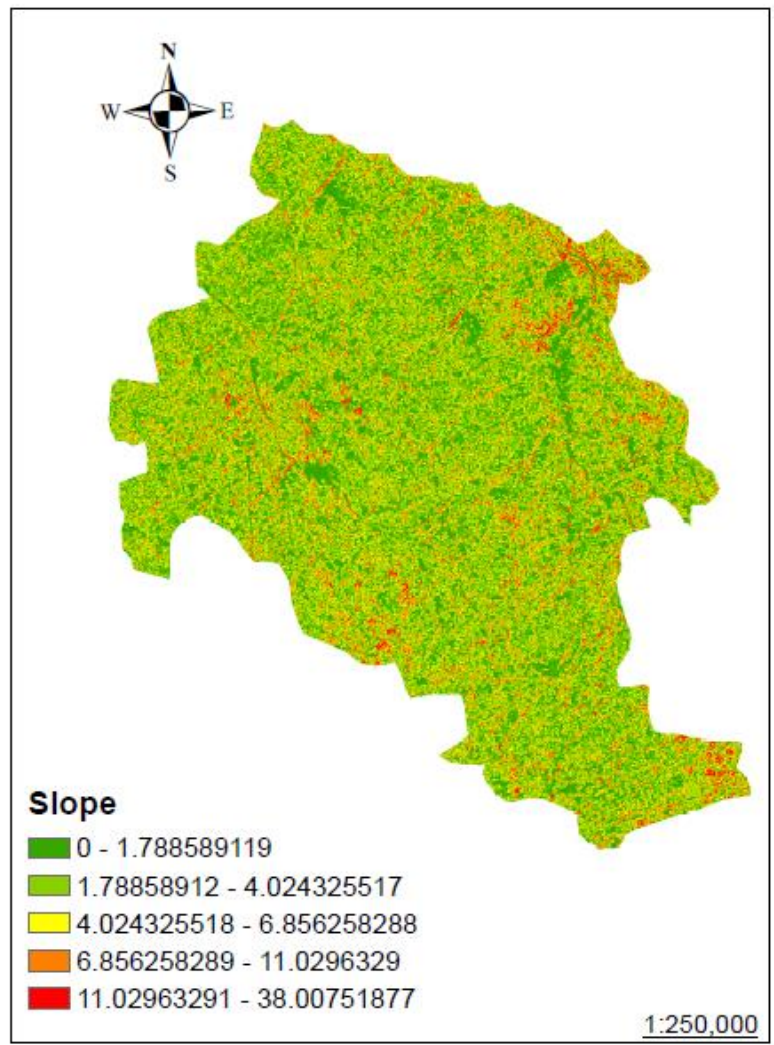

Figure 6. Slope map of study area

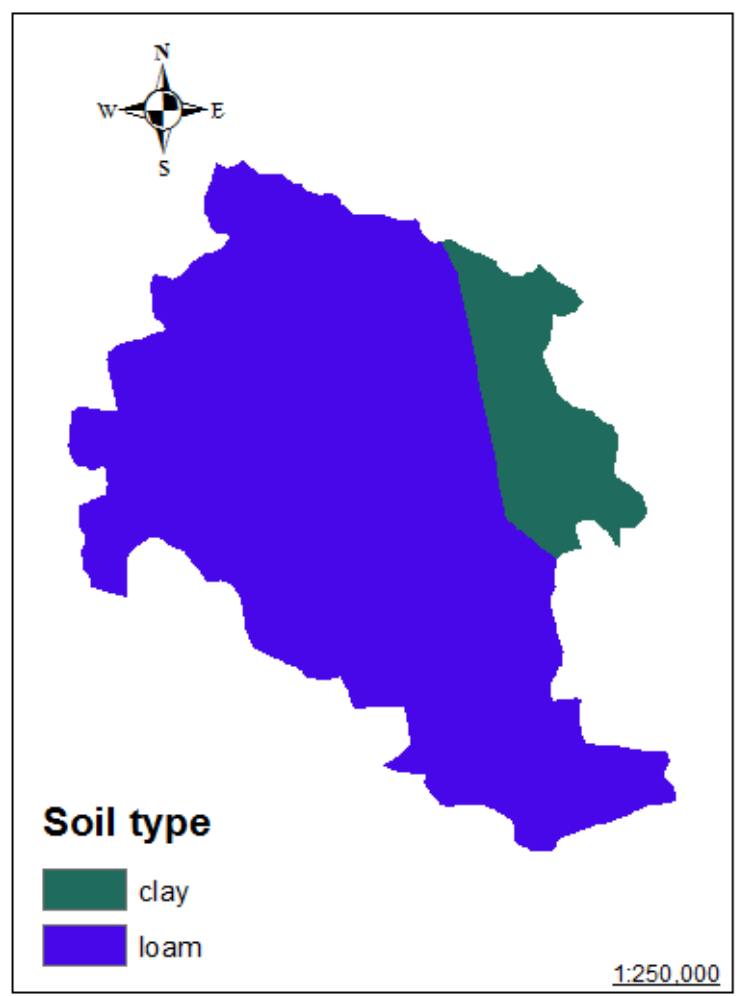

Figure 8 . Soil map of study area

\section{Soil}

Soil is an important factor for delineating the groundwater potential zones. The soil map has been prepared from FAO soil data. (FAO Geonetwork, digital soil map of the world, ESRI shape file)The analysis of the soil type reveals that the study area is predominantly

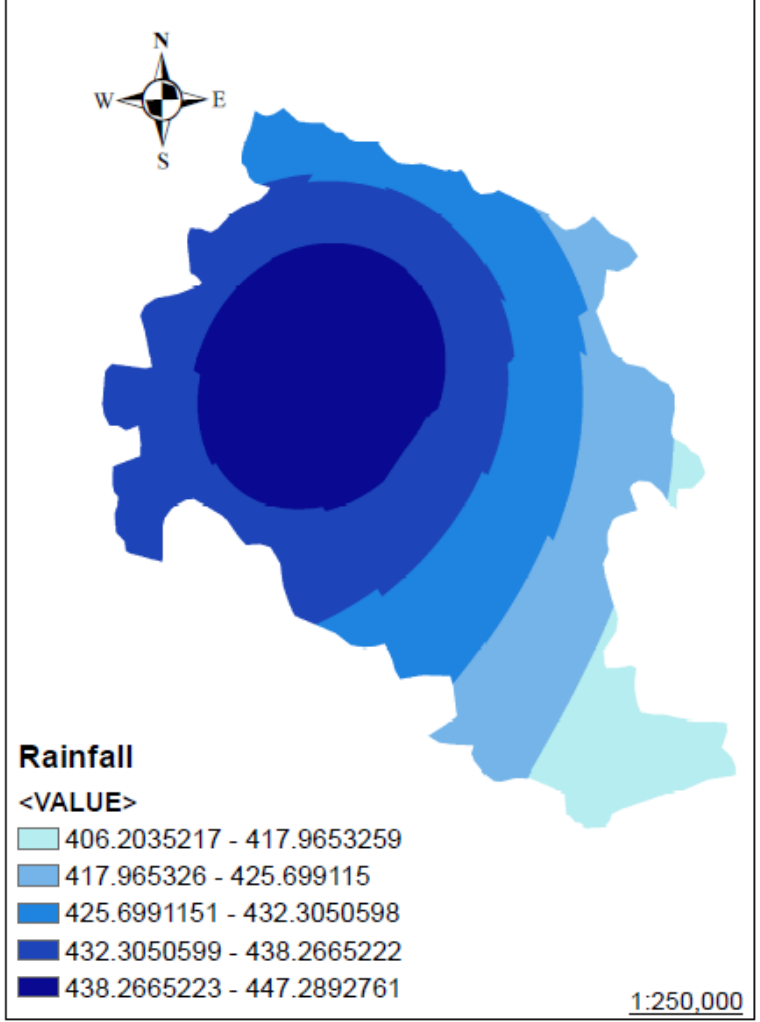

Figure 7. Rainfall map of study area

covered by clayey soil and clay loamy soil (in the lower elevation) at some places as shown in Fig. 8.

\section{Weighted overlay analysis}

There are many factors that affect the groundwater potential zone such as drainage density, rainfall, slope of the ground, types of soil, land use and land cover of that area and DEM of the study area. These factors are used for delineating groundwater potential zone, using weighted overlay analysis tool the result are being examined. This shows in table 1. The effect of each influencing factor may contribute to delineate the groundwater potential zones. Moreover, these factors are interdependent.

The final stage involved combining all thematic layers using the method that are modified from DRASTIC model. This model is used to assess ground water pollution vulnerability by Environmental Protection Agency of the United State of America. (Bennett et al., 1985) The output has been classified into five groups such as very high, high, moderate, low and very low using the quantile classification method. Groundwater potential index (GWPI) in the present study has been determined by the formula (Nath et al., 2000) as shown below:

GWPI $=\left(G_{g}{ }^{w} G_{g}{ }^{r}+D_{g}{ }^{w} D_{g}{ }^{r}+D_{d}{ }^{w} D_{d}{ }^{r}+L_{h}{ }^{w} L_{h}{ }^{r}+L_{t}{ }^{w} L_{t}{ }^{r}+\right.$ $\left.\mathrm{L}_{\mathrm{d}}{ }^{\mathrm{w}} \mathrm{L}_{\mathrm{d}}{ }^{\mathrm{r}}+\mathrm{W}_{\mathrm{w}}{ }^{\mathrm{w}} \mathrm{W}_{\mathrm{w}}{ }^{\mathrm{r}}+\mathrm{S}_{\mathrm{s}}{ }^{\mathrm{w}} \mathrm{S}_{\mathrm{s}}{ }^{\mathrm{r}}\right) /$ Total weight

\section{Groundwater potential zones}

The groundwater potential zones for the study area were generated through the integration of various thematic maps viz., drainage, slope, soil, rainfall and land-use 
using remote sensing and GIS techniques. The demarcation of groundwater potential zones for the study area was made by grouping of the interpreted layers through weighted multi influencing factor and finally assigned different potential zones.

Table 1. Classification of weighted overlay analysis

\begin{tabular}{|c|c|c|c|}
\hline Sr. No. & factor & Weightage & $\%$ influence \\
\hline \multirow{6}{*}{1} & \multicolumn{2}{|l|}{ DEM } & \multirow{6}{*}{30} \\
\hline & $79-128$ & 5 & \\
\hline & $128-153$ & 4 & \\
\hline & $153-176$ & 3 & \\
\hline & $176-200$ & 2 & \\
\hline & $200-297$ & 1 & \\
\hline \multirow{6}{*}{2} & \multicolumn{2}{|c|}{ Drainage density } & \multirow{6}{*}{30} \\
\hline & $0-0.359266694$ & 1 & \\
\hline & $0.359266694-0.750233391$ & 2 & \\
\hline & $0.750233391-1.130633421$ & 3 & \\
\hline & $1.130633421-1.55330012$ & 4 & \\
\hline & $1.55330012-2.694500208$ & 5 & \\
\hline \multirow{6}{*}{3} & \multicolumn{2}{|l|}{ Rainfall } & \multirow{6}{*}{15} \\
\hline & $406.2035217-417.9653259$ & 1 & \\
\hline & 417.965326 - 425.699115 & 2 & \\
\hline & $425.6991151-432.3050598$ & 3 & \\
\hline & $432.3050599-438.2665222$ & 4 & \\
\hline & $438.2665223-447.2892761$ & 5 & \\
\hline \multirow{6}{*}{4} & \multicolumn{2}{|c|}{ Lad-use \& Land-cover } & \multirow{6}{*}{10} \\
\hline & Urban & 3 & \\
\hline & Agriculture & 4 & \\
\hline & Barren land & 2 & \\
\hline & Waterbody & 5 & \\
\hline & Urban plantation & 1 & \\
\hline \multirow{3}{*}{5} & \multicolumn{2}{|l|}{ Soil } & \multirow{3}{*}{10} \\
\hline & clay & 1 & \\
\hline & Ioam & 2 & \\
\hline \multirow{6}{*}{6} & \multicolumn{2}{|l|}{ Slope } & \multirow{6}{*}{5} \\
\hline & $0-1.788589119$ & 5 & \\
\hline & $1.78858912-4.024325517$ & 4 & \\
\hline & $4.024325518-6.856258288$ & 3 & \\
\hline & $6.856258289-11.0296329$ & 2 & \\
\hline & $11.02963291-38.00751877$ & 1 & \\
\hline
\end{tabular}

The groundwater potential zone of this study area can be divided into five classes, namely very good, good, poor, very poor and excellent (Shaban et al, 2014).

The groundwater potential map (Fig. 8) demonstrates that the 'excellent' groundwater potential zone is covered by around $1 \%$ of total area of the tehsil. Groundwater potential zone having 'very good' class covered by $23 \%$ of the total area, 'good' zone include around $47 \%$ of the total area, area having 'poor' groundwater potential zone is $27 \%$ and 'very poor' include $2 \%$ of total area. This indicates that, soil type and slope plays a vital role in groundwater augmentation. Finally, the cumulative effect of the weighted multi influencing factors through overlay analysis in GIS platform revealed the mapping of groundwater potential zones in the study area.

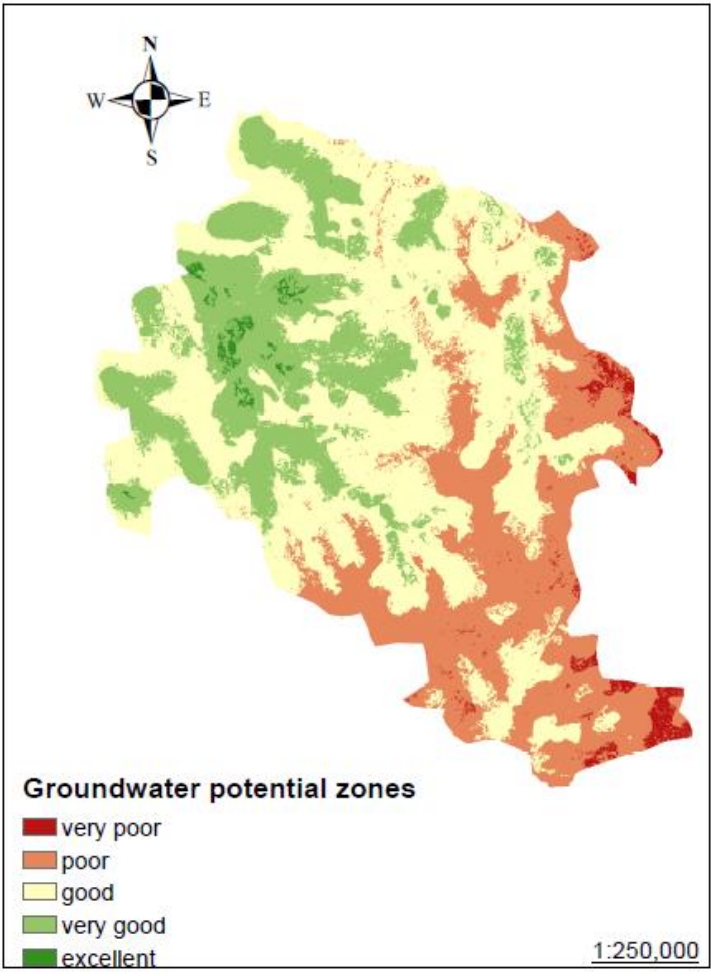

Figure 9. Groundwater potential zones

\section{Conclusion}

Delineating the groundwater potential zones in Rajkot tehsil of Gujarat using remote sensing and GIS techniques is found efficient to minimize the time, labor and money and thereby enables quick decision-making for sustainable water resources management. Satellite imageries, topographic maps and conventional data were used to prepare the thematic layers of drainage density, slope, soil, land-use and rainfall. The various thematic layers are assigned proper weightage then integrated in the GIS environment to prepare the groundwater potential zone map of the study area. According to the groundwater potential zone map, Rajkot tehsil is categorized into five different zones, namely 'excellent', 'very good', 'good', 'poor', and 'very poor'. The results of the present study can serve as guidelines for planning future artificial recharge projects in the study area in order to ensure sustainable groundwater utilization. This is an empirical method for the exploration of groundwater potential zones using remote sensing and GIS, and it succeeds in proposing potential sites for groundwater zones. This method can be widely applied to a vast area with rugged topography for the exploration of suitable sites.

\section{References}

Barut, İ. (2015). Origin of groundwater salinity and hydrogeochemical processes in a confined coastal karst aquifer: A cause of the Mandalia Bay (southeastern Aegean Sea coasts). International Journal of Environment and Geoinformatics, 2(1), 25-46, doi. 10.30897/ijegeo.303015

Biswas A., Jana A. Sharma S. P., (2012) Delineation of Groundwater Potential Zones using Satellite Remote 
Sensing and Geographic Information System Techniques: A Case study from Ganjam district, Orissa, India, Research Journal of Recent Sciences 1(9), 59-66.

Chauhan, K., Patel, J., Shukla, S., Kalubarme, M., (2021). Monitoring Water Spread and Aquatic Vegetation using Spectral Indices in Nalsarovar, Gujarat State-India. International Journal of Environment and Geoinformatics, 8(1), 49-56, doi. 10.30897/ijegeo.790839.

Dr., Lakshmi, S., Vidhya, Reddy Vinay Kumar (2018) Identification of groundwater potential zones using GIS and remote sensing. International Journal of Pure and Applied Mathematics 119 (17), 3195- 3209.

Gazioğlu, C., Aipar, B., Yücel, Z., Müftüoğlu, A., Güneysu, C., Ertek, T., Demir, V., Kaya, H. (2014). Morphologic Features of Kapıdağ Peninsula and its Coasts (NW-Turkey) using by Remote Sensing and DTM. International Journal of Environment and Geoinformatics, 1(1), 48-63, doi. 10.30897/ ijegeo.300739

Giri, D. N., Bharadwaj, P. (2012). Study and Mapping of Ground Water Prospect using Remote Sensing, GIS and Geoelectrical resistivity techniques - a case study of Dhanbad district, Jharkhand, India. Journal: Indian Geophics Union, 16(2), 55-63

Kalubarme, M., Acharya, M., Shukla, S. (2019). Monitoring Drought and its impact on Agriculture using Drought Indices and Geo-informatics Technology in Patan District, Gujarat. International Journal of Environment and Geoinformatics, 6(2), 153-162, doi. 10.30897/ijegeo.554465.

Khorrami, B., Valizadeh Kamran, K., Roostaei, S. (2018). Assessment of Groundwater-Level Susceptibility to Degradation Based on Analytical Network Process (ANP). International Journal of Environment and Geoinformatics, 5(3), 314-324, doi. 10.30897/ijegeo.451067

Krishnamurthy, J. Venkatesa, K. N., Jayaraman, V. and Manivel, M. (1996). "An approach to demarcate groundwater potential zones through remote sensing and geographic information system". Int. Journal of Remote Sensing 17, 1867-1884.

Menteş, E., Kaya, Ş., Tanık, A., Gazioğlu, C. (2019). Calculation of Flood Risk Index for Yesilirmak BasinTurkey. International Journal of Environment and Geoinformatics, 6(3), 288-299, doi. 10.30897/ ijegeo.661533

Murthy, K.S.R., (2000). Groundwater potential in a semi-arid region of Andhra Pradesh- a geographical information system approach. International Journal of Remote Sensing 21, 1867- 1884.

Panchal, J., Shukla, S., Kalubarme, M . (2021). Analysis of Optimum Growth Stages for Winter Crop Separability using Multi-Temporal NDVI Profiles in Vijapur Taluka, Gujarat State. International Journal of Environment and Geoinformatics, 8(2), 135-143, doi. 10.30897/ijegeo.803303.

Prabhu, M. V., \& Venkateswaran, S. (2015). Delineation of Artificial Recharge Zones Using Geospatial Techniq Naduues in Sarabanga Sub Basin Cauvery River, Tamil. Aquatic Procedia, 4(Icwrcoe), 12651274
Prasad, R.K., Mondal, N.C., Banerjee, P., Nandakumar, M.V., Singh, V.S. (2008). Deciphering potential groundwater zone in hard rock through the application of GIS. Environmental Geology 55, 467-475.

Rahmati, O., Nazari Samani, A., Mahdavi, M., Pourghasemi, H. R., Zeinivand, H. (2015). Groundwater potential mapping at Kurdistan region of Iran using analytic hierarchy process and GIS. Arabian Journal of Geosciences, 8(9), 7059-7071.

Ramu, M. B., Vinay, M. (2014). Identification of ground water potential zones using GIS and Remote Sensing Techniques: A case study of Mysore taluk Karnataka. International Journal of Geomatics and Geosciences, 5(3), 393-403.

Shankar, M.N.R., Mohan, G., (2006). Assessment of the groundwater potential and quality in Bhatsa and Kalu river basins of Thane district, western Deccan Volcanic Province of India. Environmental Geology 49, 990-998

Waikar, M.L., Nilawar, A. P. (2014). Identification of Groundwater Potential Zone using Remote Sensing and GIS Technique. International Journal of Innovative Research in Science, Engineering and Technology (12163-12174)

Yammani S. (2007). Groundwater quality suitable zones identification: application of GIS, Chittoor area, Andhra Pradesh, India”. Env Geol, 53(1):201-210. 